\title{
Gamma Radiation Measurements of Naturally Occurring Radioactive in Igneous Rocks and Its Radiological Complications
}

\author{
Jamilah Al-Zahrani \\ Physics Department, Faculty of Science, King Abdulaziz University, Jeddah, Saudi Arabia \\ Email: jalzhrani@kau.edu.sa
}

How to cite this paper: Al-Zahrani, J. (2017) Gamma Radiation Measurements of Naturally Occurring Radioactive in Igneous Rocks and Its Radiological Complications. World Journal of Nuclear Science and Technology, 7, 136-144.

https://doi.org/10.4236/wjnst.2017.73012

Received: May 9, 2017

Accepted: June 12, 2017

Published: June 15, 2017

Copyright $\odot 2017$ by author and Scientific Research Publishing Inc. This work is licensed under the Creative Commons Attribution International License (CC BY 4.0).

http://creativecommons.org/licenses/by/4.0/

\begin{abstract}
The concentrations of natural radioactivity were measured in igneous rock samples collected from Albaha region in the south west of Saudi Arabia. A high purity germanium (HPGe) detector was used for analysis. The average activity concentrations for ${ }^{226} \mathrm{Ra},{ }^{232} \mathrm{Th}$ and ${ }^{40} \mathrm{~K}$ were $35,31.52$ and $843.63 \mathrm{~Bq}$ $\mathrm{kg}^{-1}$, respectively. The average absorbed dose rate was $70.86 \mathrm{nGy} \cdot \mathrm{h}^{-1}$ with a corresponding average annual effective dose $0.09 \mathrm{mSv} \cdot \mathrm{y}^{-1}$. The average radium equivalent activity value was $145.84 \mathrm{~Bq} \cdot \mathrm{kg}^{-1}$, lower than the international limit $370 \mathrm{~Bq} \cdot \mathrm{kg}^{-1}$. The external and internal indices average values were 0.39 and 0.49 , respectively. The average results obtained in this study are lower than the average national and world recommended values, therefore, there is no health risk to the populace of the area. This study provides a baseline map of background radioactivity levels in the Saudi environment and will be used as reference information to assess any changes in the level background due to geological processes.
\end{abstract}

\section{Keywords}

Natural Radioactivity, Radium, Thorium and Potassium Concentrations, Hazard Index

\section{Introduction}

The importance of this study is based on the igneous rocks. These rocks are divided into different types: the melting of solid rock and the crystallization of molten rock. Some igneous rocks such as granite and basalt have other purposes in industries and commercials due to their high clay mineral element. Therefore, the radioactive contents of various radionuclides in rocks may play an important role in health conditions and geoscientific research. These radionuclides create 
risk exposure both externally and internally due to their gamma-ray emissions, their radon and progenies. The main natural contributor to external exposure is from the original radionuclides, such as ${ }^{40} \mathrm{~K}$, and the radionuclides from ${ }^{238} \mathrm{U}$ and ${ }^{232} \mathrm{Th}$ series and their decay materials [1]. Conducting an assessment, the activity of these radionuclides in the environmental samples is necessary to control the radiation levels [2]. The radioactive elements of various radionuclides in rocks may affect the health. Thus, numerous studies have been performed in many regions of the world, and the obtained data can be used to establish if the local controls are needed [3]-[10]. The major objective of this work is to estimate the radiological effects of the specific activities of ${ }^{226} \mathrm{Ra},{ }^{232} \mathrm{Th}$ and ${ }^{40} \mathrm{~K}$ in some rock samples collected from a part of the south west in Saudi Arabia (Albaha region). According to a literature survey, there are no previous data for the rock activities in the studied region. The present data are of great interest in the environmental radiation protection study and may be helpful as a baseline in making estimations of population's exposure in Saudi Arabia. These results are useful, since these types of rocks are available in the building and ornamental materials.

\section{Description of Study Area}

This study was carried out in Albaha region in the south west of Saudi Arabia. This region lies on Longitude $41^{\circ} \mathrm{E}, 42^{\circ} \mathrm{E}$ and Latitude $19^{\circ} \mathrm{N}, 20^{\circ} \mathrm{N}$. It is the smallest of the Kingdom's provinces (11,000 square $\mathrm{km}$ ) and has a population of 533,001 . This specific region has been chosen for this study due to its rocky location where there is a variety of igneous rocks used as building materials. In addition, no previous significant work about radioactivity has been done. The studied area was illustrated in Figure 1.

\section{Material and Methods}

\subsection{Samples}

Thirty igneous rock samples have been collected randomly from various locations in Albaha region, southwestern part of Saudi Arabia. In the laboratory the rocks were crushed and pulverized to a uniform mixture, dried in an oven at $110^{\circ} \mathrm{C}$ and sieved to a particulate size of about $2 \mathrm{~mm}$. About $500 \mathrm{mg}$ of powder

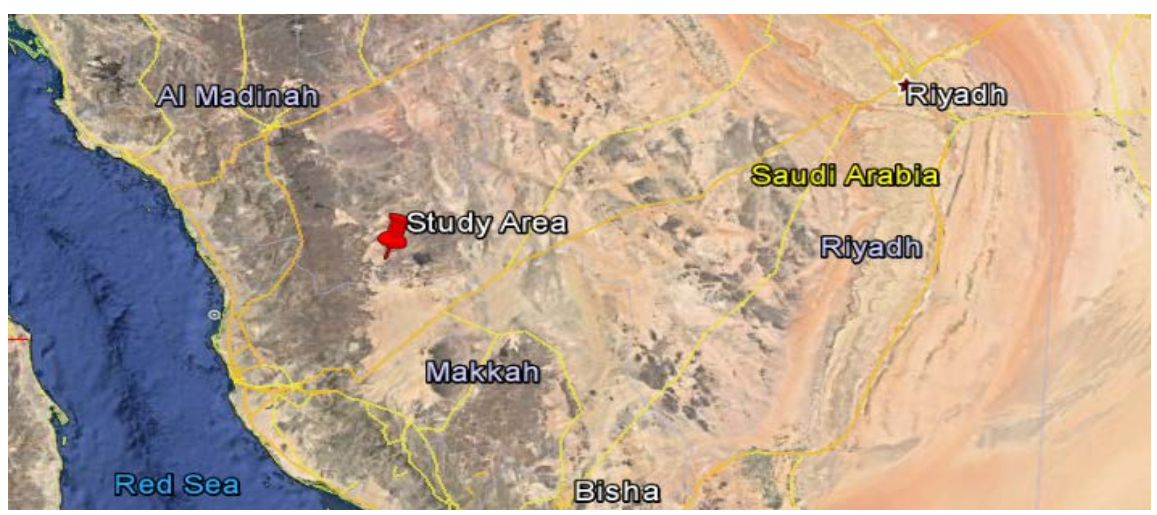

Figure 1. Location map of the study area. 
samples were filled with Polyethylene containers, sealed for four weeks before measurement to reach secular equilibrium between ${ }^{226} \mathrm{Ra}$ and ${ }^{232} \mathrm{Th}$ and their decay products [11].

\subsection{Measurements}

The gamma-rays emitted by the rock samples were measured by using High Purity Germanium (HPGe) detector gamma-ray spectrometry system of 1.85 $\mathrm{keV}$ resolution and $25 \%$ relative efficiency with coaxial-type vertical dipstick cryostat. It is surrounded by lead and copper, which provides an efficient suppression of background gamma radiation present at the laboratory. The system has a resolution (FWHM) of $(3.0-3.5 \mathrm{keV})$ for $1332.5 \mathrm{keV}$ gamma-ray peak of ${ }^{60} \mathrm{Co}$ and a peak to a Compton ratio of $41: 1$. The spectra were analyzed by commercially available software GE-NIE-2000 obtained from Canberra, USA. Counting of samples and background was done for 36,000s duration. The activity concentration for ${ }^{226} \mathrm{Ra}$ was determined by using the average obtained by gamma peaks at $351.87 \mathrm{keV}, 295.09(214 \mathrm{~Pb})$ and $609.31 \mathrm{keV}, 1120.27 \mathrm{keV}$, $1764.49 \mathrm{keV}(214 \mathrm{Bi})$, while ${ }^{232} \mathrm{Th}$ from gamma peaks $238.63 \mathrm{keV}(212 \mathrm{~Pb})$ and $911.21 \mathrm{keV}(228 \mathrm{Ac})$, finally, ${ }^{40} \mathrm{~K}$ from $1460 \mathrm{keV}$ gamma peak. The radioactivity concentrations of ${ }^{226} \mathrm{Ra},{ }^{232} \mathrm{Th}$, and ${ }^{40} \mathrm{~K}$ in the environmental samples were calculated using the following relation [10] [11] [12]:

$$
A=N c / \varepsilon \gamma m
$$

where $A$ is the activity concentration in $\mathrm{Bq} \cdot \mathrm{kg}^{-1}, N C$ is the net gamma counting rate (counts per second), $\varepsilon$ the detector efficiency of the definite Gamma-ray, $\gamma$ is the absolute transition probability of Gamma-decay and $\mathrm{m}$ the mass of the sample $(\mathrm{kg})$.

\subsection{Calculations}

The radium equivalent activity of the granite samples was calculated by using the formula [1] [11] [12]:

$$
\mathrm{Iraq}=\mathrm{ARa}+1.43 \mathrm{ATh}+0.077 \mathrm{Ak}
$$

where ARa, ATh and Ak are the activity concentrations of ${ }^{226} \mathrm{Ra},{ }^{232} \mathrm{Th}$ and ${ }^{40} \mathrm{~K}$, respectively. This formula is based on the assumption that $370 \mathrm{~Bq} \cdot \mathrm{kg}^{-1}$ of $226 \mathrm{Ra}$, $259 \mathrm{~Bq} \cdot \mathrm{kg}^{-1}$ of ${ }^{232} \mathrm{Th}$ and $481 \mathrm{~Bq} \cdot \mathrm{kg}^{-1}$ of ${ }^{40} \mathrm{~K}$ produce the same gamma-ray dose rate [13]. A value of $370 \mathrm{~Bq} \cdot \mathrm{kg}^{-1}$ corresponds to $1 \mathrm{mSv} \cdot \mathrm{y}^{-1}$.

The external hazard index $\left(H_{\mathrm{ex}}\right)$ is a radiation hazard index defined by [14]. This index value must be less than unity to keep the radiation hazard insignificant, i.e., the radiation exposure due to the radioactivity of construction materials to be limited to $1.5 \mathrm{mSv} \cdot \mathrm{years}^{-1}$ [15], based on the formula [14]:

$$
H_{\text {ex }}=\mathrm{ARa} / 370+\mathrm{ATh} / 259+\mathrm{Ak} / 4810
$$

In order to address the radiation hazard to respiratory organs due to ${ }^{222} \mathrm{Rn}$ and its radiation hazard to respiratory organs due to ${ }^{222} \mathrm{Rn}$ and its progeny, the internal hazard index $H_{\text {in }}$ which is given by [14]:

$$
H_{\text {in }}=\mathrm{ARa} / 185+\mathrm{ATh} / 259+\mathrm{Ak} / 4810
$$


where ARa, ATh and Ak are the activity concentrations of ${ }^{226} \mathrm{Ra},{ }^{232} \mathrm{Th}$ and ${ }^{40} \mathrm{~K}$, respectively. For safe, use of a material in the construction of dwellings, $H_{\mathrm{ex}}$ and $H_{\text {in }}$ should be less than unity [16].

The total air absorbed dose rate $\left(\mathrm{nGy} \cdot \mathrm{h}^{-1}\right)$ due to the activity concentrations of ${ }^{238} \mathrm{U},{ }^{232} \mathrm{Th}$, and ${ }^{40} \mathrm{~K}(\mathrm{~Bq} / \mathrm{kg})$ can be calculated using the activity concentration (in $\left.\mathrm{Bq} \cdot \mathrm{kg}^{-1}\right)$ of ${ }^{40} \mathrm{~K}(A K),{ }^{226} \mathrm{Ra}(A R a)$ and ${ }^{232} \mathrm{Th}(A T h)$ substituted into the formula [1]:-

$$
\mathrm{D}=0.0417 \mathrm{Ak}+0.462 \mathrm{ARa}+0.604 \mathrm{ATh}
$$

The annual effective dose equivalent (AEDE) was calculated from the absorbed dose by applying the dose conversion factor of $0.7 \mathrm{SvG} \cdot \mathrm{y}^{-1}$ with an outdoor occupancy factor of $0.2[1]$ :

$$
\operatorname{AEDE}(\mathrm{mSv} / \mathrm{y})=\mathrm{D}(\mathrm{nGy} / \mathrm{h}) \times 8760(\mathrm{~h} / \mathrm{y}) \times 0.7(\mathrm{~Sv} / \mathrm{Gy}) \times 0.2 \times 10^{-6}
$$

\section{Results and Discussion}

Table 1 shows the values of activity concentration of ${ }^{226} \mathrm{Ra},{ }^{232} \mathrm{Th}$ and ${ }^{40} \mathrm{~K}$ and the corresponding radiological hazards were obtained from thirty rock samples collected from Albaha region in the South west of Saudi Arabia. From this Table, it can be seen that the activity concentrations of ${ }^{40} \mathrm{~K}$ varied between $124.19 \mathrm{~Bq} \cdot \mathrm{kg}^{-1}$ in sample (R9) to $2353.19 \mathrm{~Bq} \cdot \mathrm{kg}^{-1}$ in sample (R27) with a mean value of 843.63 $\mathrm{Bq} \cdot \mathrm{kg}^{-1} \cdot{ }^{226} \mathrm{Ra}$ concentrations varied from $7.39 \mathrm{~Bq} \cdot \mathrm{kg}^{-1}$ in sample (R21) to 82.85 $\mathrm{Bq} \cdot \mathrm{kg}^{-1}$ in sample (R27) with a mean of $35 \mathrm{~Bq} \cdot \mathrm{kg}^{-1}$. The concentrations of ${ }^{232} \mathrm{Th}$ varied from $12.09 \mathrm{~Bq} \cdot \mathrm{kg}^{-1}$ in sample (R15) to $82.96 \mathrm{~Bq} \cdot \mathrm{kg}^{-1}$ in sample (R7) with a mean value of $31.52 \mathrm{~Bq} \cdot \mathrm{kg}^{-1}$. The mean activity concentration values for ${ }^{226} \mathrm{Ra}$ and, ${ }^{232} \mathrm{Th}$ were lower than the recommended radioactivity levels of 50, 50 as reported by UNSCEAR 2000 , while ${ }^{40} \mathrm{~K}$ mean concentration was found to be greater than the global value $500 \mathrm{~Bq} \cdot \mathrm{kg}^{-1}$. The variations of natural radioactivity levels in different samples are due to the variation of concentrations of these elements in the geological formations. The high activity concentration of ${ }^{40} \mathrm{~K}$ in some rock samples may be attributed to the presence of relatively increased amount of accessory minerals such as zircon, iron oxides, fluorite and other radioactive related minerals [17] [18]. In general, Potassium-40 is usually of limited interest because it is an isotope of an essential element, controlled in the human cells [19]. However, the ${ }^{40} \mathrm{~K}$ mean value of this study is still more below the rigid control $100,000 \mathrm{~Bq} \cdot \mathrm{kg}^{-1}$ as given by IAEA [20]. So, the present results indicated that, the activity concentrations in the rock samples are quite uniform and do not show any considerable variation. Figure 2 shows the activity concentration of uranium, potassium and radium in the collected samples. Figure $3(\mathrm{a})$ and Figure $3(\mathrm{~b})$ show that there is a good linear correlation $\left(R^{2}=0.80\right.$ and 0.83 ) between the activity concentration of $\mathrm{Ra}$, Th and Ra, K, respectively. Table 1 summarized the results of the hazard parameters as the following:-

The values of Raeq for all samples range from 53.72 to $339.36 \mathrm{~Bq} \cdot \mathrm{kg}^{-1}$ with a mean value145.84 $\mathrm{Bq} \cdot \mathrm{kg}^{-1}$. These obtained values were below the recommended maximum value of $370 \mathrm{~Bq} \cdot \mathrm{kg}^{-1}$, which is equivalent to an external dose of 1.5 
Table 1. Values of radioactivity concentrations and radiation hazard parameters for rock samples under investigation.

\begin{tabular}{|c|c|c|c|c|c|c|c|c|}
\hline \multirow{2}{*}{ Sample code } & \multicolumn{3}{|c|}{ Activity concentrations $(\mathrm{Bq} / \mathrm{kg})$} & \multirow{2}{*}{$\begin{array}{l}\text { Radium-equivalent } \\
(\mathrm{Bq} / \mathrm{kg})\end{array}$} & \multirow{2}{*}{$\begin{array}{c}\text { External } \\
\text { index } \\
(\mathrm{Hex})\end{array}$} & \multirow{2}{*}{$\begin{array}{l}\text { Internal } \\
\text { index } \\
\text { (Hin) }\end{array}$} & \multirow{2}{*}{$\begin{array}{l}\text { Absorbed } \\
\text { dose(D) } \\
(\mathrm{nGy} / \mathrm{h})\end{array}$} & \multirow{2}{*}{$\begin{array}{c}\text { Annual } \\
\text { effective dose } \\
\text { (AEDE) }\end{array}$} \\
\hline & ${ }^{226} \mathrm{Ra}$ & ${ }^{232} \mathrm{Th}$ & ${ }^{40} \mathrm{~K}$ & & & & & \\
\hline $\mathrm{R} 1$ & 20.54 & 17.77 & 522.72 & 86.20 & 0.23 & 0.29 & 42.32 & 0.052 \\
\hline $\mathrm{R} 2$ & 41.84 & 23.57 & 541.15 & 117.21 & 0.32 & 0.43 & 55.82 & 0.068 \\
\hline R3 & 37.12 & 25.69 & 896.81 & 142.91 & 0.39 & 0.49 & 70.42 & 0.086 \\
\hline $\mathrm{R} 4$ & 36.02 & 21.76 & 403.56 & 98.21 & 0.27 & 0.36 & 46.29 & 0.057 \\
\hline R5 & 53.98 & 38.06 & 829.31 & 172.26 & 0.47 & 0.61 & 82.42 & 0.101 \\
\hline R6 & 35.23 & 24.86 & 699.51 & 124.64 & 0.34 & 0.43 & 60.61 & 0.074 \\
\hline R7 & 76.64 & 82.96 & 1871.31 & 339.36 & 0.92 & 1.12 & 164.88 & 0.202 \\
\hline R8 & 9.69 & 9.25 & 377.65 & 51.99 & 0.14 & 0.17 & 26.14 & 0.032 \\
\hline R9 & 29.71 & 50.58 & 124.19 & 111.60 & 0.30 & 0.38 & 49.54 & 0.061 \\
\hline R10 & 8.66 & 12.64 & 350.39 & 53.72 & 0.15 & 0.17 & 26.64 & 0.033 \\
\hline R11 & 11.59 & 15.17 & 428.75 & 66.30 & 0.18 & 0.21 & 32.84 & 0.040 \\
\hline $\mathrm{R} 12$ & 81.38 & 64.36 & 1879.83 & 318.16 & 0.86 & 1.08 & 155.68 & 0.191 \\
\hline R13 & 17.86 & 13.06 & 487.54 & 74.08 & 0.20 & 0.25 & 36.73 & 0.045 \\
\hline R14 & 31.49 & 44.46 & 1181.55 & 186.05 & 0.50 & 0.59 & 91.95 & 0.113 \\
\hline R15 & 27.65 & 12.09 & 326.86 & 70.11 & 0.19 & 0.26 & 33.39 & 0.041 \\
\hline R16 & 47.39 & 36.79 & 924.24 & 171.17 & 0.46 & 0.59 & 82.89 & 0.102 \\
\hline R17 & 43.33 & 34.22 & 1320.73 & 193.96 & 0.52 & 0.64 & 96.61 & 0.119 \\
\hline R18 & 66.75 & 54.13 & 1479.67 & 258.09 & 0.70 & 0.88 & 125.85 & 0.154 \\
\hline R19 & 45.54 & 35.68 & 1126.56 & 183.31 & 0.50 & 0.62 & 90.12 & 0.111 \\
\hline R20 & 23.49 & 30.69 & 620.75 & 115.17 & 0.31 & 0.37 & 55.84 & 0.068 \\
\hline $\mathrm{R} 21$ & 5.57 & 24.16 & 472.35 & 76.49 & 0.21 & 0.22 & 37.74 & 0.046 \\
\hline R22 & 34.54 & 22.96 & 803.35 & 129.23 & 0.35 & 0.44 & 63.60 & 0.078 \\
\hline R23 & 7.39 & 15.01 & 452.88 & 63.73 & 0.17 & 0.19 & 31.98 & 0.039 \\
\hline R24 & 20.29 & 21.58 & 835.79 & 115.51 & 0.31 & 0.37 & 58.05 & 0.071 \\
\hline R25 & 43.15 & 23.27 & 504.81 & 115.30 & 0.31 & 0.43 & 54.63 & 0.067 \\
\hline R26 & 24.79 & 18.39 & 536.27 & 92.38 & 0.25 & 0.32 & 45.10 & 0.055 \\
\hline $\mathrm{R} 27$ & 82.85 & 69.45 & 2353.19 & 223.46 & 0.98 & 1.21 & 179.83 & 0.221 \\
\hline $\mathrm{R} 28$ & 37.43 & 45.11 & 1288.81 & 317.94 & 0.54 & 0.64 & 99.50 & 0.122 \\
\hline R29 & 22.72 & 42.65 & 1128.25 & 170.58 & 0.46 & 0.52 & 84.79 & 0.104 \\
\hline \multirow[t]{2}{*}{ R30 } & 25.21 & 15.34 & 540.21 & 136.05 & 0.24 & 0.31 & 43.55 & 0.053 \\
\hline & $5.57-82.85$ & $12.09-82.96$ & $124.19-2353.19$ & $53.72-339.36$ & $0.14-0.98$ & $0.17-1.21$ & $26.14-179.83$ & $0.032-0.221$ \\
\hline Mean & 35 & 31.52 & 843.63 & 145.84 & 0.39 & 0.49 & 70.86 & 0.09 \\
\hline UNSCEAR2000 & 50 & 50 & 500 & 370 & $<1$ & $<1$ & $18-93$ & $<1$ \\
\hline
\end{tabular}

$\mathrm{mSv} \cdot \mathrm{y}^{-1}$. Therefore, the rock samples are within an acceptable safe limit. The external hazard (Hex) in the rock samples ranged from 0.14 to 0.98 with a mean 


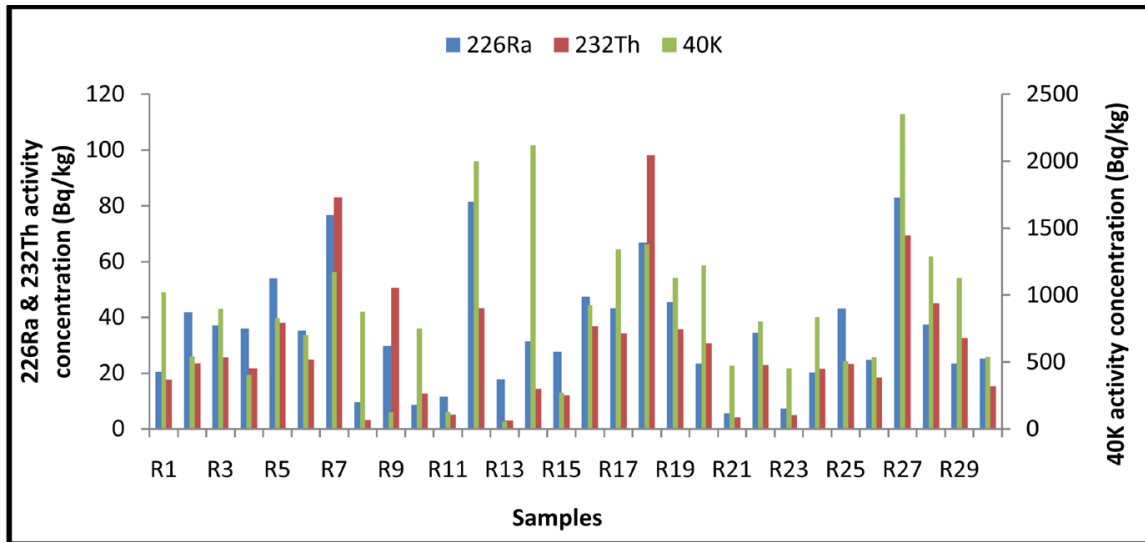

Figure 2. Activity concentrations of radionuclides ${ }^{226} \mathrm{Ra},{ }^{232} \mathrm{Th}$ and ${ }^{40} \mathrm{~K}$ in rock samples from South western, Saudi Arabia.

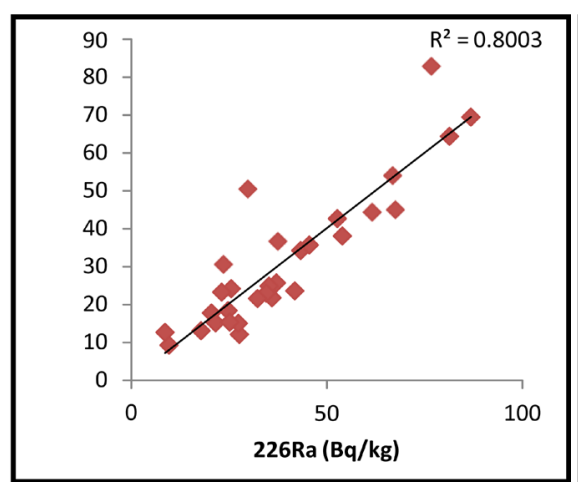

(a)

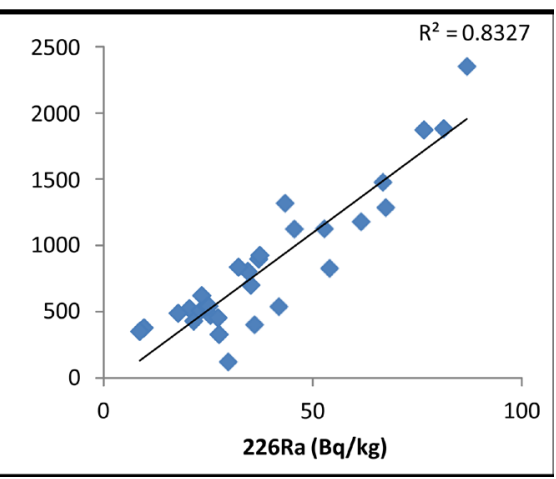

(b)

Figure 3. (a, b), Correlations between ${ }^{226} \mathrm{Ra}$ and ${ }^{238} \mathrm{U}$ and between ${ }^{226} \mathrm{Ra}$ and ${ }^{40} \mathrm{~K}$ in selected rock samples.

value of 0.39 . Also, the internal hazard (Hin), its values ranged from 0.17 to 1.21 with a mean value of 0.49 . Three samples (R7, R12, R27) had an internal hazard values above the recommended limit of 1.0 which implies that these samples are not suitable as interior building materials and may be a source of internal radon and its progeny, while the other samples have Hin values below the recommended limit. In general, for the safe use of a material in the construction of dwellings, Hex and Hin should be less than unity. The estimated absorbed dose rate varied from 26.14 to $179.83 \mathrm{nGy} \cdot \mathrm{h}^{-1}$. The mean absorbed dose rate was calculated to be $70.86 \mathrm{nGy} \cdot \mathrm{h}^{-1}$ within the typical range of worldwide average values (18 - 93) reported in UNSCEAR 2000. The calculated values of annual effective dose (AEDE) ranged from 0.032 to $0.221 \mathrm{mSv} \cdot \mathrm{y}^{-1}$ with a mean value 0.09 $\mathrm{mSv} \cdot \mathrm{y}^{-1}$. The recommended upper limit of $1 \mathrm{mSv} \cdot \mathrm{y}^{-1}$ is not exceeded in all samples. This means that these rock samples are safety for human health.

Figure 4 shows a comparison between the average radium equivalent activity $(\mathrm{Bq} / \mathrm{kg})$ and the absorbed dose rate $\left(\mathrm{nGy} \cdot \mathrm{h}^{-1}\right)$ for rock samples under investigation. Table 2 compares the average values of natural radioactivity for rocks in the present study with the obtained data for other countries. As shown in this table, the radioactivity in rock samples varied from one country to another 


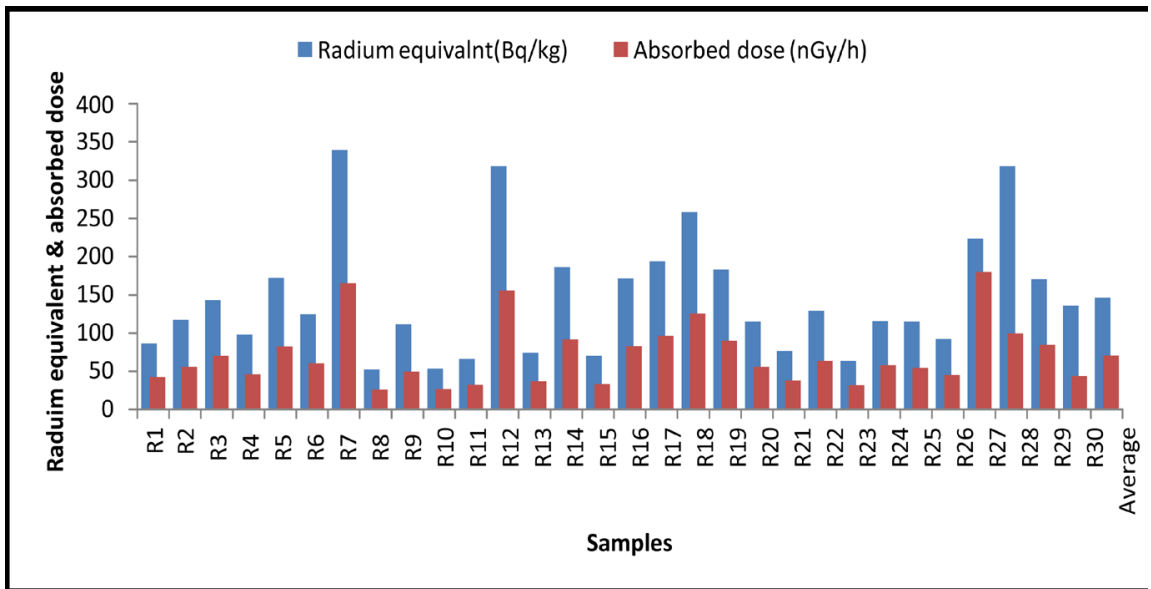

Figure 4. Radium equivalent and absorbed dose in rock samples, south western, Saudi Arabia.

Table 2. Comparison of natural radioactivity concentration $(\mathrm{Bq} / \mathrm{kg})$ in the present study with the reported values of the world.

\begin{tabular}{ccccc}
\hline \multirow{2}{*}{ Country } & \multicolumn{3}{c}{ Average activity concentration $(\mathrm{Bq} / \mathrm{kg})$} & \multirow{2}{*}{ References } \\
\cline { 2 - 5 } & $226 \mathrm{R}$ & $232 \mathrm{Th}$ & $40 \mathrm{~K}$ & \\
\hline Saudi Arabia & 35 & 31.57 & 843.63 & Present work \\
Saudi(South of Al-Madina) & 106.4 & 110.35 & 2683 & {$[12]$} \\
Egypt & 28.4 & 37.4 & 1167 & {$[11]$} \\
Yemen (Aden) & 57.086 & 80.26 & 846.21 & {$[7]$} \\
Yemen(Sana'a,) & 26.6 & 23.2 & 515.6 & {$[9]$} \\
Italy & $15-164$ & $16-174$ & $201-1350$ & {$[21]$} \\
India & 41.08 & 86.26 & 869.29 & {$[4]$} \\
Brazil & 24 & 37 & 1173 & {$[22]$} \\
Turkey & $12.01-48.95$ & $8.2-53.27$ & $143.97-452.34$ & {$[23]$} \\
\hline
\end{tabular}

depends on the locality geological conditions [9] [11] [16]. In general, the results of this study are comparable to the different published studies as listed in this Table.

\section{Conclusion}

Gamma ray spectrometry has been used to determine the radioactivity concentrations of ${ }^{226} \mathrm{Ra},{ }^{232} \mathrm{Th}$ and ${ }^{40} \mathrm{~K}$ in the rock samples, collected from Albaha region in the south west of Saudi Arabia. The results show that the activity concentrations of ${ }^{226} \mathrm{Ra}$ and ${ }^{232} \mathrm{Th}$ consent with the world-wide average recommended values. The radium equivalent activity values were below the permissible limits 370 $\mathrm{Bq} / \mathrm{kg}$. The values of external, internal hazard index and outdoor effective dose were found less than unity. Therefore, the study area is still in the zones of normal radiation level. This data may provide a guideline for future measurement and assessment of possible radiological risks to human health in this region. 


\section{References}

[1] UNSCEAR (2000) Annex B: Exposure from Natural Radiation Sources. Report to General Assembly, United Nations Scientific Committee on the Effects of Atomic Radiation (UNSCEAR), New York.

[2] Turhan, Ş., Baykan, U.N. and Şen, K. (2008) Measurement of the Natural Radioactivity in Building Materials Used in Ankara and Assessment of External Doses. Journal of Radiological Protection, 28, 83. https://doi.org/10.1088/0952-4746/28/1/005

[3] El-Bahi, S.M., et al. (2017) Radiological Impact of Natural Radioactivity in Egyptian Phosphate Rocks, Phosphogypsum and Phosphate Fertilizers. Applied Radiation and Isotopes, 123, 121-127. https://doi.org/10.1016/j.apradiso.2017.02.031

[4] Prakash, M.M., Kaliprasad, C.S. and Narayana, Y. (2017) Studies on Natural Radioactivity in Rocks of Coorg District, Karnataka State, India. Journal of Radiation Research and Applied Sciences, 10, 128-134. https://doi.org/10.1016/j.jrras.2017.02.003

[5] Rangaswamy, D.R., et al. (2016) Measurement of Natural Radioactivity and Radiation Hazard Assessment in Rock Samples of Ramanagara and Tumkur Districts, Karnataka, India. Environmental Earth Sciences, 75, 1-11. https://doi.org/10.1007/s12665-015-5195-8

[6] Zubair, M. (2015) Measurement of Natural Radioactivity in Rock Samples Using Gamma Ray Spectrometry. Radiation Protection and Environment, 38, 11-13. https://doi.org/10.4103/0972-0464.162820

[7] Harb, S., El-Kamel, A.H., Zahran, A.M., Abbady, A. and Ahmed, F.A. (2014). Natural Radioactivity Measurements of Basalt Rocks in Aden Governorate, South of Yemen on Gulf of Aden. IOSR Journal of Applied Physics (IOSR-JAP), 5, 39-48. https://doi.org/10.9790/4861-0563948

[8] Gomes, M.E.P., Martins, L.M.O., Neves, L.J.P.F. and Pereira, A.J.C.S. (2013) Natural Radiation and Geochemical Data for Rocks and Soils, in the North International Douro Cliffs (NE Portugal). Journal of Geochemical Exploration, 130, 60-64. https://doi.org/10.1016/j.gexplo.2013.03.001

[9] Harb, S., Abbady, A.E.B., El-Kamel, A.E.H., Saleh, I.I. and El-Mageed, A.I.A. (2012) Natural Radioactivity and Their Radiological Effects for Different Types of Rocks from Egypt. Radiation Physics and Chemistry, 81, 221-225. https://doi.org/10.1016/j.radphyschem.2011.11.005

[10] Najam, L.A., Firas, M.A. and Enas, M.A. (2011) Natural Radioactivity Levels of Limestone Rocks in Northern Iraq Use Gamma Spectroscopy and Nuclear Track Detector. Journal of Radioanalytical and Nuclear Chemistry, 289, 709-715. https://doi.org/10.1007/s10967-011-1144-5

[11] El-Mageed, A.A., El-Kamel, A.H., Abbady, A., Harb, S., Youssef, A.M.M. and Saleh, I.I. (2011) Assessment of Natural and Anthropogenic Radioactivity Levels in Rocks and Soils in the Environments of Juban Town in Yemen. Radiation Physics and Chemistry, 80, 710-715. https://doi.org/10.1016/j.radphyschem.2011.02.025

[12] Hamidalddin, S.H.Q. (2012) Study of Natural Radionuclides of Some Igneous Rocks in Arabian Shield (South of Al-Madinah Al-Munawarah), Saudi Arabia. Journal of American Science, 8, 1524-1529.

[13] Stranden, E.R.L.I.N.G. (1976) Some Aspects of Radioactivity of Building Materials. Physics, 8, 163-167.

[14] NEA-OECD (1979) Exposure to Radiation from Natural Radioactivity in Building Materials. Report, The Group of Experts of the OECD Nuclear Energy Agency, 
NEA, Paris.

[15] Beretka, J. and Mathew, P.J. (1985) Natural Radioactivity of Australian Building Materials, Industrial Wastes and By-Products. Health Physics, 48, 87-95. https://doi.org/10.1097/00004032-198501000-00007

[16] El-Arabi, A.M. (2007) $226 \mathrm{Ra}, 232 \mathrm{Th}$ and $40 \mathrm{~K}$ Concentrations in Igneous Rocks from the Eastern Desert, Egypt and Its Radiological Implications. Radiation Measurements, 42, 94-100. https://doi.org/10.1016/j.radmeas.2006.06.008

[17] Faanu, A., Adukpo, O.K., Tettey-Larbi, L., Lawluvi, H., Kpeglo, D.O., Darko, E.O. and Efa, A.O. (2016) Natural Radioactivity Levels in Soils, Rocks and Water at a Mining Concession of Perseus Gold Mine and Surrounding Towns in Central Region of Ghana. Springer Plus, 5, 98. https://doi.org/10.1186/s40064-016-1716-5

[18] Xinwei, L., Lingqing, W. and Xiaodan, J. (2006) Radiometric Analysis of Chinese Commercial Granites. Journal of Radioanalytical and Nuclear Chemistry, 267, 669673. https://doi.org/10.1007/s10967-006-0101-1

[19] Awudu, A.R., et al. (2012) Preliminary Studies on 226Ra, 228Ra, 228Th and 40K Concentrations in Foodstuffs Consumed by the Inhabitants of the Accra Metropolitan Area, Ghana. Journal of Radioanalytical and Nuclear Chemistry, 291, 635-641. https://doi.org/10.1007/s10967-011-1444-9

[20] IAEA (1989) International Atomic Energy Agency. Measurement of Radiation in Food and the Environment. Guidebook. Technical Report Series No. 295, IAEA, Vienna.

[21] Bella, S., Brai, M., Hauser, S., Puccio, P. and Rizzo, S. (1997) Natural Radioactivity in a Volcanic Island: Ustica, Southern Italy. Applied Radiation and Isotopes, 48, 287-293. https://doi.org/10.1016/S0969-8043(96)00150-9

[22] Pavlidou, S., et al. (2006) Natural Radioactivity of Granites Used as Building Materials. Journal of Environmental Radioactivity, 89, 48-60.

https://doi.org/10.1016/j.jenvrad.2006.03.005

[23] Akkurt, I. and Günoğlu, K. (2014) Natural Radioactivity Measurements and Radiation Dose Estimation in Some Sedimentary Rock Samples in Turkey. Science and Technology of Nuclear Installations, 2014, 1-6.

\section{Submit or recommend next manuscript to SCIRP and we will provide best service for you:}

Accepting pre-submission inquiries through Email, Facebook, LinkedIn, Twitter, etc. A wide selection of journals (inclusive of 9 subjects, more than 200 journals) Providing 24-hour high-quality service User-friendly online submission system Fair and swift peer-review system Efficient typesetting and proofreading procedure Display of the result of downloads and visits, as well as the number of cited articles Maximum dissemination of your research work

Submit your manuscript at: http://papersubmission.scirp.org/

Or contactwjnst@scirp.org 